\title{
AtBAG6, a novel calmodulin-binding protein, induces programmed cell death in yeast and plants
}

\author{
CH Kang ${ }^{1}$, WY Jung ${ }^{1}$, YH Kang ${ }^{1}$, JY Kim ${ }^{1}$, DG Kim ${ }^{1}$, JC Jeong ${ }^{1}$, \\ DW Baek ${ }^{1}$, JB Jin ${ }^{1}$, JY Lee ${ }^{1}$, MO Kim ${ }^{1}$, wS Chung ${ }^{1}$, T Mengiste ${ }^{2}$, \\ H Koiwa ${ }^{3}$, SS Kwak ${ }^{4}$, JD Bahk ${ }^{1}$, SY Lee ${ }^{1}$, JS Nam ${ }^{5}$, DJ Yun ${ }^{*, 1}$ and \\ MJ Cho ${ }^{1}$ \\ 1 Division of Applied Life Science (BK21 program) and Environmental \\ Biotechnology National Core Research Center, Graduate School of \\ Gyeongsang National University, Jinju 660-701, Korea \\ 2 Department of Botany and Plant Pathology, Purdue University, West \\ Lafayette, IN 47907-2054, USA \\ 3 Department of Horticultural Sciences, Texas A\&M University, College Station, \\ TX 77843-2133, USA \\ ${ }^{4}$ Laboratory of Environmental Biotechnology, Korea Research Institute of \\ Bioscience and Biotechnology (KRIBB), Yusong, Daejeon 305-806, Korea \\ ${ }^{5}$ Faculty of Plant Biotechnology, Dong-A University, Busan 604-714, Korea \\ * Corresponding author: DJ Yun, Division of Applied Life Science (BK21 \\ program) and Environmental Biotechnology National Core Research Center, \\ Gyeongsang National University, \#900 Gajwa Dong, Jinju 660-701, Korea. \\ Tel: + 82-55-751-6256; Fax: + 82-55-759-9363; \\ E-mail: djyun@gsnu.ac.kr
}

Received 10.9.04; revised 30.5.05; accepted 30.5.05; published online 08.7.05 Edited by B Zhivotovsky

\section{Abstract}

Calmodulin (CaM) influences many cellular processes by interacting with various proteins. Here, we isolated AtBAG6, an Arabidopsis CaM-binding protein that contains a central BCL-2-associated athanogene (BAG) domain. In yeast and plants, overexpression of AtBAG6 induced cell death phenotypes consistent with programmed cell death (PCD). Recombinant AtBAG6 had higher affinity for CaM in the absence of free $\mathrm{Ca}^{2+}$ than in its presence. An IQ motif (IQXXXRGXXXR, where $X$ denotes any amino-acid) was required for $\mathrm{Ca}^{2+}$-independent CaM complex formation and single amino-acid changes within this motif abrogated both AtBAG6-activated CaM-binding and cell death in yeast and plants. A 134-amino-acid stretch, encompassing both the IQ motif and BAG domain, was sufficient to induce cell death. Agents generating oxygen radicals, which are known to be involved in plant PCD, specifically induced the AtBAG6 transcript. Collectively, these results suggest that AtBAG6 is a stress-upregulated CaM-binding protein involved in plant PCD.

Cell Death and Differentiation (2006) 13, 84-95.

doi:10.1038/sj.cdd.4401712; published online 8 July 2005

Keywords: calcium; calmodulin; CaM-binding protein; IQ motif; BAG domain; stress; Arabidopsis

Abbreviations: CaM, calmodulin; CaMBPs, CaM-binding proteins; BAG, BCL-2-associated athanogene; AtBAG, Arabidopsis thaliana BAG; CDD, cell death domain; GST, glutathione
S-transferase; HRP, horse radish peroxidase; PCD, programmed cell death; ROS, reactive oxygen species

\section{Introduction}

In both plants and animals, the cytosolic free calcium level $\left(\left[\mathrm{Ca}^{2+}\right]_{\text {cyt }}\right)$ is normally maintained at submicromolar levels, but can be transiently elevated with complex forms of amplitude, frequency and duration by specific external stimuli. $^{1,2}$ Transiently elevated $\left[\mathrm{Ca}^{2+}\right]_{\text {cyt }}$ in the cell leads to binding of $\mathrm{Ca}^{2+}$ to intracellular regulatory proteins, initiating a wide variety of cellular processes. ${ }^{3}$ Calmodulin (CaM) is a ubiquitous $\mathrm{Ca}^{2+}$ receptor protein that regulates the activities and functions of a wide range of CaM-binding proteins (CaMBPs), including metabolic enzymes, transcription factors, ion channels, protein kinases/phosphatases, and structural proteins. ${ }^{4,5}$

The overall shape of CaM is a dumbbell, with the $\mathrm{N}$ - and $\mathrm{C}$ terminal globular domains separated by a flexible central helix. $\mathrm{Ca}^{2+}$-binding to $\mathrm{CaM}$ induces conformational changes that facilitate binding of $\mathrm{Ca}^{2+} / \mathrm{CaM}$-dependent target proteins and subsequent modulation of their biological activities. ${ }^{6}$ Although considerable research has focused on the $\mathrm{Ca}^{2+}$. bound form of CaM, it is known that the $\mathrm{Ca}^{2+}$-free state of CaM, apocalmodulin (ApoCaM), also binds to other (or overlapping) proteins and signals cellular responses. ${ }^{7,8}$ ApoCaM differs from $\mathrm{Ca}^{2+}$-bound $\mathrm{CaM}$ in its three-dimensional structure, and it also binds target proteins differently, utilizing binding motifs such as the IQ motif (IQXXXRG XXXR) and noncontiguous binding sites. ${ }^{9,10}$ Therefore, CaM may cycle between $\mathrm{Ca}^{2+}$-free and $\mathrm{Ca}^{2+}$-bound states, and bind different proteins in each state to trigger specific cellular functions. ${ }^{10}$

In plant cells, $\mathrm{Ca}^{2+}$-signaling is implicated in diverse processes, including thigmomorphogenesis, light signal transduction, gibberellic acid signaling, pathogen-challenged defense signaling, and salt stress signaling. ${ }^{11,12}$ Since CaM is known to transduce $\mathrm{Ca}^{2+}$-signals by modulating the activity of numerous and diverse CaMBPs, thereby generating physiological responses to various stimuli, many CaM and CaMBPs have been isolated with a view to furthering our understanding of $\mathrm{Ca}^{2+}$-mediated plant signaling pathways. ${ }^{13-15}$ However, many aspects of plant CaM and CaMBPs signaling, as well as their functional significance, remain unclear.

BAG (BCL2-associated athanogene) family proteins were originally identified in mammals due to their ability to associate with the antiapoptotic protein, BCL2, and promote cell survival. ${ }^{16}$ Further studies revealed that BAG family genes exist in a number of eukaryotes whose members share at least one copy of a 50 amino-acid conserved domain (BAG domain) that interacts with heat shock protein 70 (HSP70/ HSC70). ${ }^{16-18}$ BAG proteins may serve as bridging molecules that recruit $\mathrm{HSP} 70 / \mathrm{HSC} 70$ to a specific target protein. As a consequence, this family of cochaperones functionally 
regulates diverse cellular pathways, such as programmed cell death (PCD) and stress responses. ${ }^{19}$ While information is available on the biological roles of BAG proteins in mammals, no plant homologs of BAG family members have been functionally characterized to date.

To determine the biological role(s) of CaM in plants, we have previously isolated a number of $\operatorname{CaMBP}(\mathrm{s}) .^{20-22}$ Here, we report the isolation and characterization of an Arabidopsis gene encoding a BAG protein homolog (AtBAG6). Our data indicate that AtBAG6 expression in yeast and plant cells induces cell death. Furthermore, the IQ motif within the AtBAB6 sequence is required for $\mathrm{Ca}^{2+}$-independent complex formation with CaM and AtBAG6-mediated cell death in yeast and plant. This is the first documented evidence that a BAG domain protein is involved in $\mathrm{Ca}^{2+} / \mathrm{CaM}$-mediated signaling in eukaryotes.

\section{Results}

\section{Cloning AtBAG6 encoding a CaM-binding protein}

To unequivocally establish the role of CaM-mediated signaling in plants, many CaMBPs that may link $\mathrm{Ca}^{2+} / \mathrm{CaM}$ signals to specific responses have been cloned. ${ }^{13,14,23}$ In this study, we screened an Arabidopsis cDNA expression library constructed from heat-treated plant seedlings using AtCaM2::HRP as a probe. ${ }^{20,22}$ In all, 11 positive clones were obtained from a total of $5 \times 10^{5}$ recombinant phages. Based on the restriction patterns of plasmid inserts, the genes coding for CaMBPs were classified into seven different loci. Since the protein encoding CaMBP1 conferred the highest CaM-binding activity (data not shown), this gene was selected for further study. Proteins encoded by other CaMBPs are not structurally related to $C a M B P 1$, and will be described elsewhere.

Sequence determination of CaMBP1 and comparison to sequences within GenBank ${ }^{\mathrm{TM}}$ revealed that the nucleotide sequence of the $2105 \mathrm{bp}$ cDNA clone contains a partial coding region (encoding 674 amino acids) and a full $3^{\prime}$-untranslated region. The $5^{\prime}$-truncated region of the CDNA was recovered by RACE-PCR, and sequenced. The 3170 nucleotide full-length cDNA contained an open reading frame encoding a putative $117 \mathrm{kDa}$ protein consisting of 1043 amino-acid residues identical to AtBAG6 (accession no. At2g46240). ${ }^{24}$ Accordingly, CaMBP1 was redesignated AtBAG6 (Figure 1). In mammals, BAG domain proteins interact with other proteins to modulate cellular processes. To identify the plant proteins
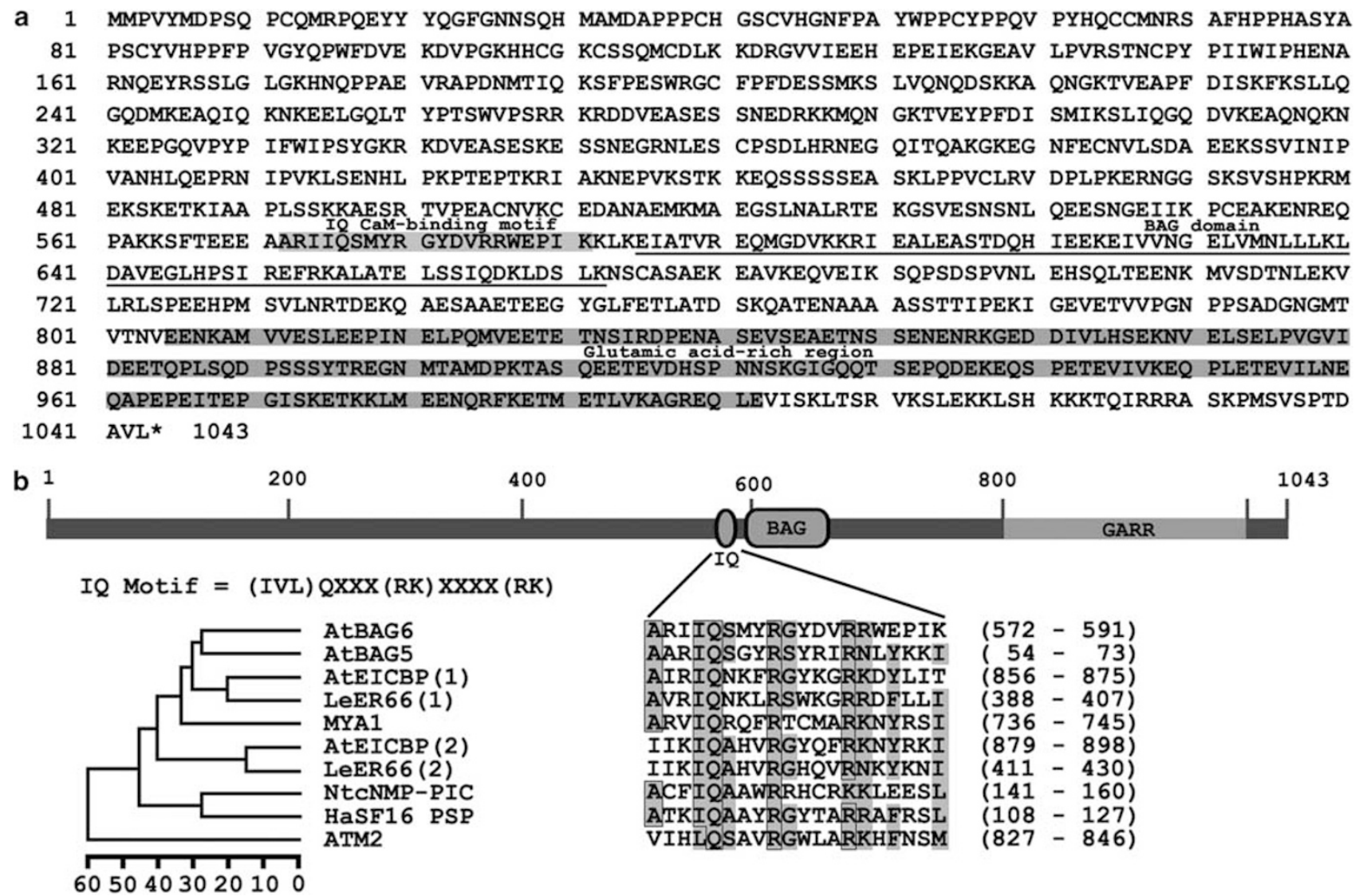

Figure 1 Deduced amino-acid sequence of AtBAG6 and comparison of its putative CaMBD (IQ motif) to ones of other CaM-binding proteins. (a) Deduced amino-acid sequence of AtBAG6. The predicted CaMBD (light gray), BAG domain (underlined) and glutamic acid-rich regions (dark grey) are indicated. (b) Schematic representation of AtBAG6 and alignment of protein sequences from AtBAG6 with CaMBDs from AtBAG5 (A. thaliana BAG domain containing protein; NP_172670), AtEICBP (A. thaliana EICBP protein; AC007168), LeER66 (Lycopersicon esculentum ER66 protein; AAD46410), MYA1 (A. thaliana myosin MYA1; S46444), NtcNMP-RIC (Nicotiana tabacum CaMB-channel protein; AAB53255), HaSF16 PSP (Helianthus annuus SF16 protein; CAA52782), and ATM2 (A. thaliana myosin MYA1; S46444). Amino-acid residues identical to the consensus CaMBD sequences are depicted in black 
associated with AtBAG6, we employed the yeast two-hybrid screening system using full-length AtBAG6 as bait. We identified 33 yeast colonies that expressed both reporter genes $\left(A d e^{+} / / a c Z^{+}\right)$in an $A t B A G 6$-dependent manner. Sequence analyses revealed that all the AtBAG6-associated proteins are AtCaM isoforms, specifically, five AtCaM1s (accession no. At5g37780), 14 AtCaM2s (accession no. At2g41110), seven AtCaM3s (accession no. At3g56800), two AtCaM4s (accession no. At1g66410), three AtCaM6s (accession no. At5g21274) and two AtCaM7s (accession no. At3g43810). These results indicate that AtBAG6 mainly interacts with AtCaM isoforms in vivo.

\section{Mapping of CaMBD within AtBAG6}

Comparative sequence analysis of AtBAG6 with other known proteins revealed the presence of a putative CaM-binding IQ motif $^{25-28}$ and a BAG domain ${ }^{17-19}$ in the middle of the sequence (Figure 1). A glutamic acid-rich region was identified near the carboxyl terminus of the protein sequence on a database using the ScanProsite program (http:// www.expasy.org/cgi-bin/scanprosite). ${ }^{29}$ To determine the CaM-binding regions in AtBAG6, we performed the CaM::HRP overlay assay with Escherichia coli-expressed recombinant AtBAG6 proteins. To this end, we generated GST-fused constructs containing full-length cDNA (designated D0) and five serial deletion derivatives of AtBAG6 (D1, D2, D3, D4, and CDD) (Figure 2a). Recombinant proteins were produced in E. coli, purified, and verified by anti-GST polyclonal antibodies. The molecular weight (MW) of recombinant AtBAG6 was much higher than the calculated size (the expected MW of DO is about $143 \mathrm{kDa}$ ) (Figure 2b). This difference may result from the anomalous electrophoretic mobility caused by the large number of Glu residues within the AtBABG6 sequence, which reduce SDS binding. ${ }^{30,31}$ Four recombinant proteins (D0, D2, D3, and CDD) containing the putative CaMBD interacted with AtCaM2::HRP, whereas GST only (data not shown) and GST fusion proteins lacking the predicted IQ motif (D1 and D4) did not interact with AtCaM2::HRP (Figure 2b). Importantly, CaM bound AtBAG6 in the absence, but not the presence of $\mathrm{Ca}^{2+}$. Similar results were obtained when 6-His-tagged AtBAG6 recombinant proteins were used to perform this assay (data not shown).

\section{Crucial residues of the CaM-binding motif}

Comparative analysis of the CaM-binding regions of many CaMBP proteins has led to the identification of multiple sequence motifs required for CaM complex formation., ${ }^{26} \mathrm{We}$ identified a putative IQ motif, a structural characteristic of CaMBDs that has been identified previously, between $\mathrm{Ala}^{572}$ and Lys ${ }^{591}$ of AtBAG6 (Figure 1). To further determine whether the IQ motif in the region is required for CaM-binding, we separately substituted $11 \mathrm{e}^{575}$ in the CDD (described in Figure 1a) with Val, Ser, and Asn (designated CDD ${ }^{1575 \mathrm{~V}}$, $\mathrm{CDD}^{1575 \mathrm{~S}}$ and CDD ${ }^{1575 \mathrm{~N}}$, respectively) (Figure 3a). Recombinant proteins were produced in E. coli and analyzed for CaMbinding activity using the CaM overlay assay. CaM bound to the wild-type CDD and CDD ${ }^{1575 V}$ but not to $C D D^{1575 S}$ or
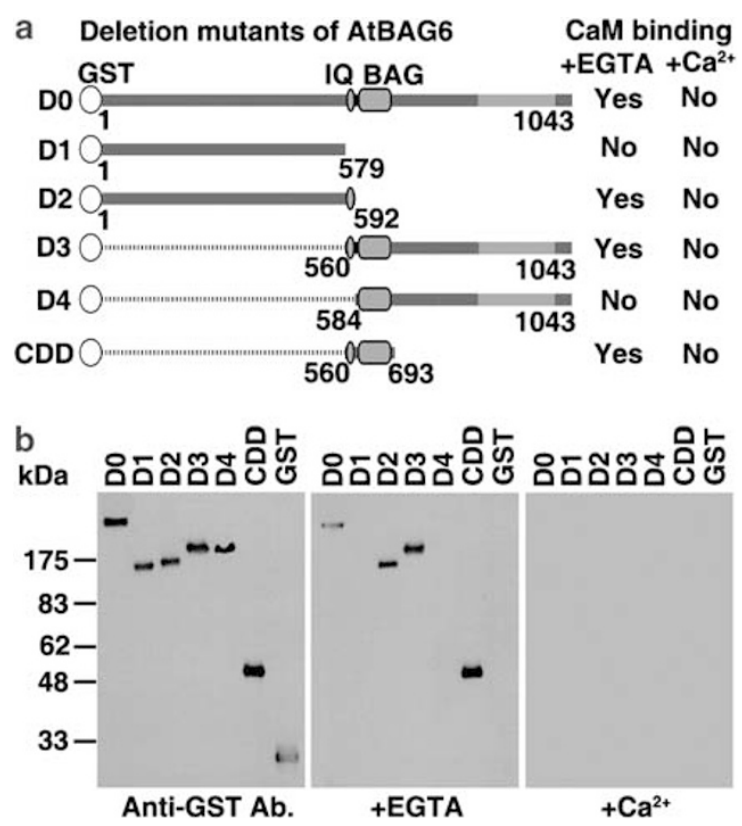

Figure 2 Identification of the CaM-binding domain of AtBAG6. (a) Schematic representation of AtBAG6 (D0) and serial fragment constructs (D1-D4, and $\mathrm{CDD}$ ). The IQ motif and BAG domain are depicted by a circle and a box, respectively. Amino-acid positions of each serial fragment are indicated. D0-D4, and CDD represent six GST fusion constructs containing the indicated fragments of AtBAG6. CaM-binding ability is indicated as Yes (CaM-binding) or No (no CaM-binding). (b) CaM-binding analysis. Six GST fusion proteins of serial fragment mutants (D0-D4, and CDD) of AtBAG6 were produced in E. coli. The recombinant proteins were analyzed by Western blotting with an anti-GST antibody (left panel). The CaM::HRP overlay assay was performed in the absence (5 mM EGTA, middle panel) or presence ( $1 \mathrm{mM} \mathrm{CaCl}_{2}$, right panel) of $\mathrm{Ca}^{2+}$

$\mathrm{CDD}^{1575 \mathrm{~N}}$ mutant proteins (Figure 3a). Similar results were obtained when we performed the yeast two-hybrid assay with full-length AtBAG6 and AtCaM2 (Figure 3b). Taken together, these results indicate that $\| e^{575}$ in AtBAG6 is crucial for interactions and specific complex formation with AtCaMs.

\section{Induction of cell death by AtBAG6 in yeast}

The BAG domain was originally identified in human cells, based on its ability to bind to BCL2 (an antiapoptotic protein) and promote cell survival. ${ }^{16,32}$ Accordingly, we investigated whether the biological function of AtBAG6 is associated with cell survival by expressing the protein in a unicellular yeast system. A cDNA encoding full-length AtBAG6 was subcloned into the episomal pYES2 vector under control of the GAL1 promoter, which allows for the conditional expression of this protein when cells are grown in galactose-containing medium. Unexpectedly, we found that expression of AtBAG6 in yeast cells induced cell death (Figure 4a).

More than eight genes have been identified in Arabidopsis that encode proteins with a BAG domain. ${ }^{24}$ To investigate whether other members of this family are also involved in yeast cell death, two AtBAG6 paralogues, AtBAG1 (At5g52060) and AtBAG8 (At3g29310), were transformed into yeast cells. The amino acid similarities between the BAG domain of AtBAG6 and those of AtBAG1 and AtBAG8 are 58, and $52 \%$, respectively. Expression of AtBAG6 dramatically 
a

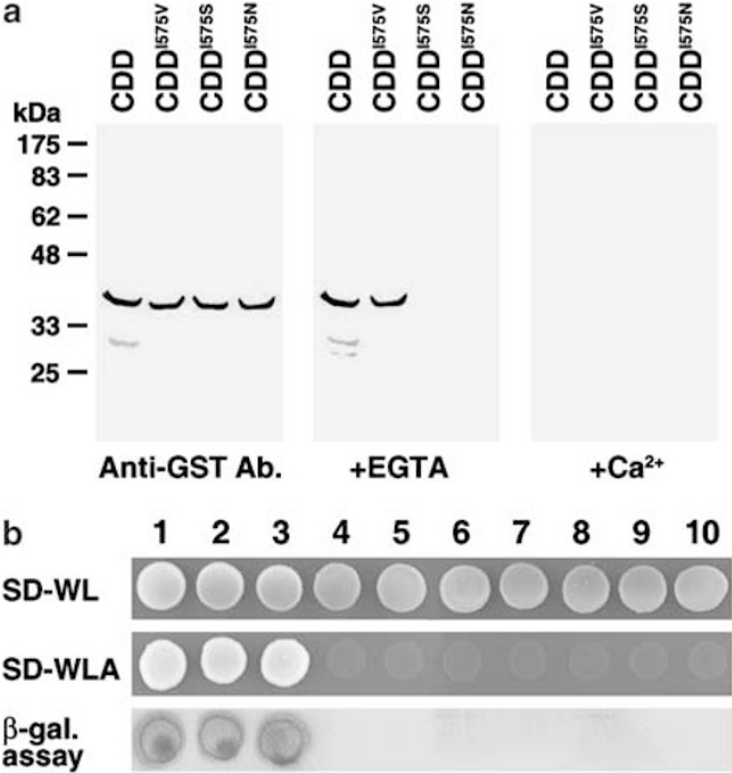

Figure 3 Characterization of the IQ motif of AtBAG6. (a) CaM-binding to the IQ motif of $C D D$ in vitro. $C D D$ mutants that contain single amino-acid substitutions were fused to the C-terminus of GST, and expressed in E. coli. The recombinan proteins were analyzed by Western blotting with an anti-GST antibody (left panel). The CaM::HRP overlay assay (described in Materials and Methods) was performed in the absence (5 mM EGTA, middle panel) or presence $\left(1 \mathrm{mM} \mathrm{CaCl}_{2}\right.$ right panel) of $\mathrm{Ca}^{2+} \cdot \mathrm{CDD}^{1575 \mathrm{~V}}, \mathrm{CDD}^{1575 \mathrm{~S}}$ and $\mathrm{CDD}^{1575 \mathrm{~N}}$ represent replacement of $I e^{575}$ in the IQ motif with Val, Ser, and Asn, respectively. (b) Interactions between AtBAG6 and AtCaM2 in yeast. The indicated combinations of bait (pGBT9) and prey (pGAD424) constructs were transformed into the yeast reporter strain, PJG69-4. Transformants were examined for growth in the absence of Trp, Leu (SD-WL) or Trp, Leu, Ade (SD-WLA) and for the $\beta$ galactosidase assay. (1) interactions between tumor suppressor p53 (pTD1-1) and simian virus 40 large T-antigen ( $p V A 3-1)$; (2) interactions between wild-type AtBAG6 (BD::AtBAG6) and AtCaM2 (AD::AtCaM2); (3) interactions between AtBAG6 $6^{1575 \mathrm{~V}}$ (BD::AtBAG6 $6^{1575 \mathrm{~V}}$ ) and AtCaM2 (AD::AtCaM2); (4) interactions between AtBAG6 ${ }^{1575 S}$ (BD::AtBAG6 ${ }^{1575 S}$ ) and AtCaM2 (AD::AtCaM2); (5) interactions between AtBAG6 $6^{1575 \mathrm{~N}}\left(B D:: A t B A G 6^{1575 N}\right)$ and AtCaM2 (AD::AtCaM2); (6) BD vector (pGBT9) and AD::AtCaM2; (7) BD::AtBAG6 and $A D$ vector (pGAD424); (8) BD::AtBAG6 ${ }^{1575 V}$ and $A D$ vector (pGAD424); (9) BD::AtBA$G 6^{1575 S}$ and $A D$ vector (pGAD424); $10, B D:: A t B A G 6^{1575 N}$ and $A D$ vector (pGAD424)

induced cell death; however, transformants expressing AtBAG1 or AtBAG8 did not exhibit cell death (Figure 4a). This suggests that, of the Arabidopsis BAG proteins, AtBAG6 is a specific cell death inducer.

The cell death phenotype induced by AtBAG6 was further confirmed by trypan blue exclusion and 4', 6'-diamino-2phenylindole dihydrochloride (DAPI) staining (Figure $4 \mathrm{~b}$ and data not shown). DAPI staining revealed that the majority of cells not expressing AtBAG6 had a normal and single roundshaped nucleus, whereas an abundance of abnormally shaped and fragmented nuclei (approximately 50\%) was observed in the cells expressing AtBAG6 (Figure 4b). Expression of AtBAG6 also resulted in exposure of phosphatidylserine on the surface of the cytoplasmic membrane, as revealed by FITC-annexin $\mathrm{V}$ staining (Figure 4c), as well as the occurrence of DNA strand breaks, demonstrated by TUNEL assay (Figure 4b). ${ }^{33,34}$ Furthermore, alterations associated with cell death induced by AtBAG6 included abnormal morphology, cell shrinkage, increased vacuolation
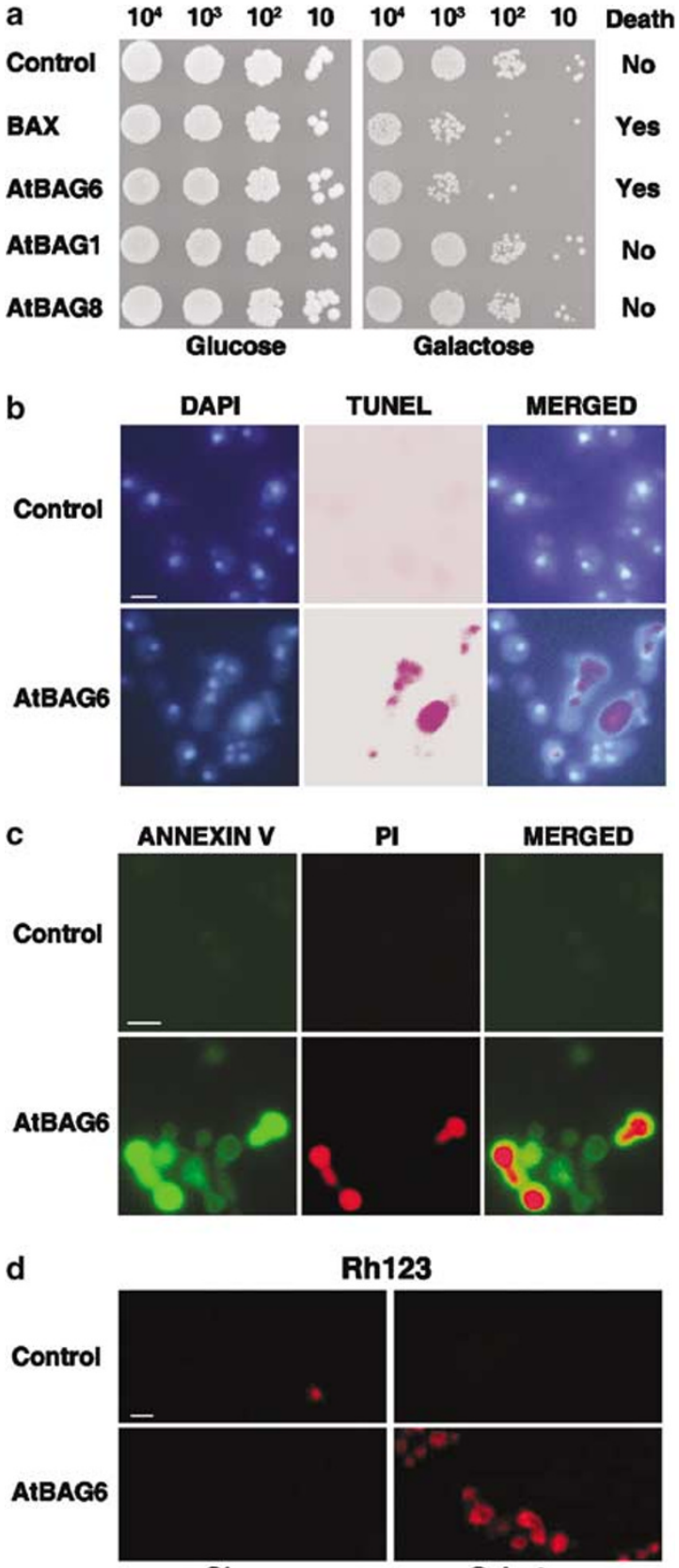

Rh123

Glucose

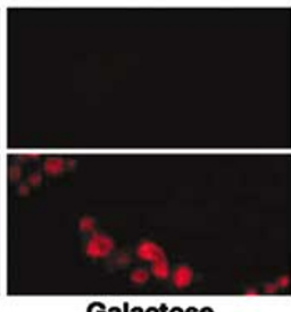

Figure 4 AtBAG6 induces cell death in yeast. (a) Functional analysis of Arabidopsis BAG family proteins in yeast cells. Yeast cells transformed with plasmid pYES2 (control) containing BAX (Moon et al., ${ }^{85}$ ), AtBAG6, AtBAG1, or AtBAG8 were cultured in glucose-based medium to an $\mathrm{OD}_{600}$ of $\sim 1.0$ at $30^{\circ} \mathrm{C}$ for $12 \mathrm{~h}$. Equal numbers of cells were spotted on minimal SD medium plates in the presence of glucose or galactose, as described in Materials and Methods. Photographs were taken after culturing at $30^{\circ} \mathrm{C}$ for 2 days. (b, c, and d) AtBAG6induced programmed cell death in yeast. Yeast cells transformed with plasmid pYES2 (control) containing AtBAG6 grown on either glucose or galactose were stained with DAPI-TUNEL (for detection of cell death and DNA strand breaks), Annexin V-PI (for detection of exposed phophatidylserine), or dihydrorhodamine123 (Rh123, for detection of reactive oxygen generation), respectively. Experimental conditions were described in Materials and Methods. Scale bar, $5 \mu \mathrm{m}$

without membrane rupture, and loss of plasma membrane integrity (data not shown). All these morphological characteristics are hallmarks of apoptosis. ${ }^{34-36}$ 
Reactive oxygen species (ROS) have been implicated as effectors of PCD in animal and yeast cells. ${ }^{37,38}$ Accordingly, the role of ROS in AtBAG6-induced cell death was examined. Production of ROS was monitored using dihydrorhodamine123. Upon oxidation by ROS, nonfluorescent dihydrorhodamine123 changes into the fluorescent chromophore, rhodamine123. ${ }^{39}$ As shown in Figure 4d, yeast cells expressing AtBAG6 exhibited strong fluorescence when incubated with dihydrorhodamine123, whereas control cells grown in glucose-containing medium exhibited no significant fluorescence, suggesting that the generation of ROS may mediate AtBAG6-induced cell death in yeast.

\section{Requirement of the IQ motif and BAG domain for AtBAG6-mediated cell death}

To identify the critical domain in AtBAG6 responsible for inducing cell death, deletion mutant clones of AtBAG6 (depicted in Figure $2 \mathrm{a}$ and Supplementary Figure 1) were subcloned into the pYES2 vector and cell death phenotypes were investigated (Figure 5 and Supplementary Figure 1). Colonies formed by yeast cells harboring all of the constructs on glucose-based medium were detected with approximately the same efficiency as control transformants (Figure 5, left panel). However, transformants harboring both the IQ motif and BAG domain (D0, D3, CDD) showed greatly reduced colony formation on galactose medium (Figure 5, right panel).

To further investigate the significance of CaM-AtBAG6 interactions in AtBAG6- mediated cell death, we investigated the cell death phenotype of AtBAG6 containing a single amino-acid substitution in the IQ motif (described in Figure 3). Transformants harboring full-length AtBAG6 or AtBAG6 $6^{1575 \mathrm{~V}}$ (Ile ${ }^{575}$ substituted with Val) resulted in a dramatic decrease in colony formation and cell viability on galactose medium. However, those containing AtBAG $6^{1575 S}$ or AtBAG6 $6^{1575 N}$ (lle ${ }^{575}$ substituted with Ser or Asn, respectively) displayed similar colony-forming efficiency in glucose- or galactose-

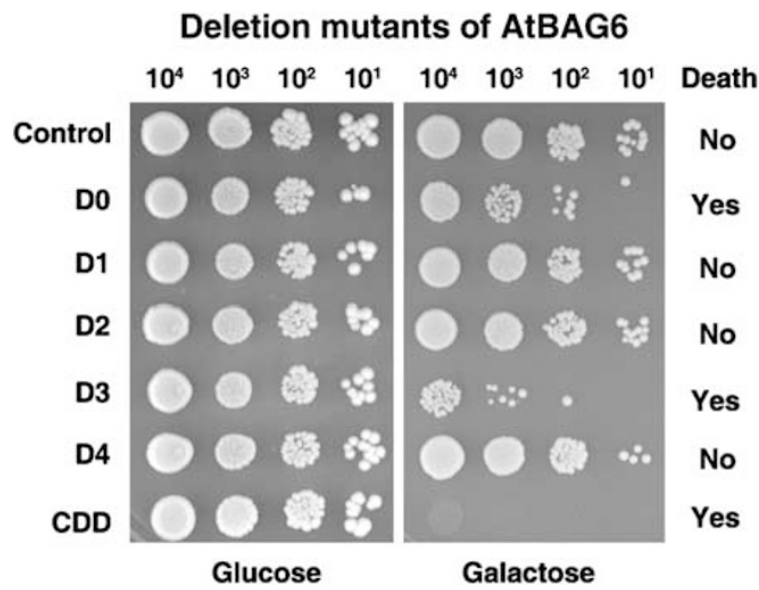

Figure 5 Identification of the cell death domain in AtBAG6. The specified constructs depicted in Figure 2 were transformed into the yeast strain, W303a. Equal numbers of cells were spotted on minimal SD medium plates in the presence of glucose or galactose, as described in Materials and Methods. Photographs were taken after culturing at $30^{\circ} \mathrm{C}$ for 2 days. Inducibility of cell death is indicated as Yes (inducible) or No (not inducible) based medium (Figure 6a). Similar results were obtained when the CDD domain was tested with these mutations (Figure $6 \mathrm{~b}$ and data not shown). Taken together, these results provide strong evidence that the CaM-binding domain is required for AtBAG6-mediated cell death in yeast.

\section{AtBAG6 does not bind AtHSC70, an Arabidopsis heat shock protein}

Since BAG family proteins in animals are known to interact with and regulate the activity of HSP70/HSC70 (heat shock proteins of relative molecular mass $70 \mathrm{kDa}$ ) family molecular chaperones, we investigated whether AtBAG6 interacted with AtHSC70 (accession no. X74604) - a plant homolog of animal HSP70/HSC70. GST fusion proteins of AtBAG6, CDD (a fragment from $\operatorname{Gln}^{560}$ to Pro $^{693}$ of AtBAG6), and two AtBAG6 paralogues, AtBAG3 (At5g07220) and AtBAG5 (At1g12060), were produced in E. coli and analyzed for their ability to interact with 6-His-tagged AtHSC70 by far-Western blot analysis. ${ }^{16,17}$ AtBAG3 and AtBAG5 bound to the AtHSC70, whereas AtBAG6 and CDD did not (Figure 7 and data not shown).
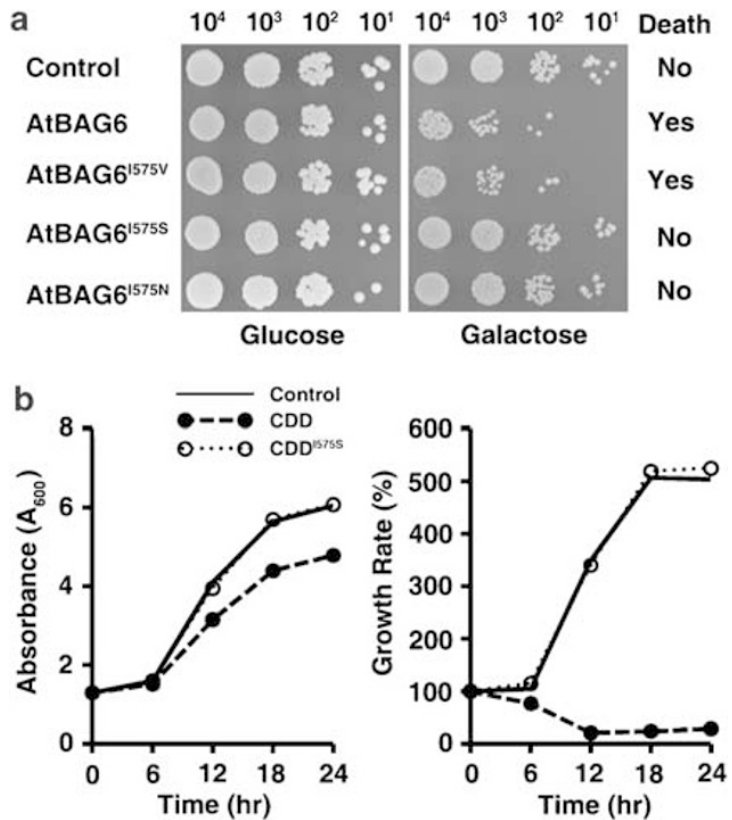

Figure 6 CaM-binding IQ motif is required for AtBAG6-induced cell death. (a) pYES2 vector (control) containing full-length AtBAG6, or AtBAG6 mutants that contain single amino-acid substitutions were transformed into a yeast strain, W303a. Equal numbers of cells were spotted on minimal SD medium plates in the presence of glucose or galactose, as described in Materials and Methods. Photographs were taken after culturing at $30^{\circ} \mathrm{C}$ for 2 days. AtBAG6 $6^{1575 \mathrm{~V}}$, AtBAG6 ${ }^{1575 S}$ and AtBAG6 ${ }^{1575 \mathrm{~N}}$ represent replacement of $11 e^{575}$ in the AtBAG6 with Val, Ser, and Asn, respectively. (b) pYES2 vector (control) containing a CDD (depicted in Figure 2), or a $C D D$ mutant $\left(C D D^{1575 S}\right.$ substitution of $11 e^{5 / 5}$ in the CDD domain with Ser) were transformed into a yeast strain, W303a. Transformants were grown in glucose-based medium to an $\mathrm{OD}_{600}$ of 1.0 , washed three times with water, and then cultured for $0-24 \mathrm{~h}$ in fresh glucose medium. The optical densities of the media at $\mathrm{OD}_{600}$ were measured (left panel). The same cultures in the left panel $\left(10^{3}\right.$ cells) were plated on galactose-based medium. The number of viable cells was determined after incubating the plates at $30^{\circ} \mathrm{C}$ for 3 days, and the data were normalized to the value of cells cultured in glucose medium 


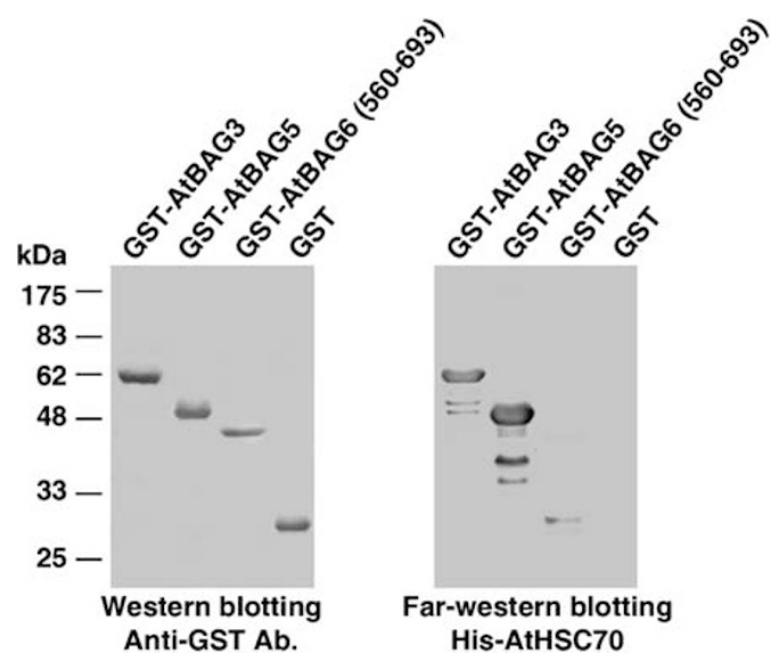

Figure 7 AtBAG6 does not interact with AtHSC70. Recombinant GST and GST-AtBAG3, GST-AtBAG5, and GST-AtBAG6 (560-693) proteins were expressed in E. coli. In all, $20 \mu \mathrm{g}$ of crude extract was resolved by $12 \%$ SDSPAGE, transferred onto a PVDF membrane, and detected with anti-GST (left panel). A duplicate membrane was probed with recombinant His-AtHSC70 and followed by detection with anti-His that is conjugated to horseradish peroxidase (right panel) to determine if HSP70 can bind to the BAG recombinant proteins

\section{Induction of cell death by AtBAG6 in Arabidopsis plant}

To investigate the function of AtBAG6 in a plant species, we initially determined AtBAG6 gene expression under various stress conditions. Total RNA was isolated from stress-treated Arabidopsis seedlings and Northern blot analysis was performed using AtBAG6 cDNA as a probe (Figure 8). Transcription of AtBAG6 was specifically induced by $\mathrm{SA}$, $\mathrm{H}_{2} \mathrm{O}_{2}$, and high temperature, all of which are known to be involved in plant PCD processes. ${ }^{40-43}$

To further determine the biological roles of AtBAG6 in plants, we constructed each plasmid containing $C D D$ or $C D D^{15755}$ under the control of the constitutive cauliflower mosaic virus $35 \mathrm{~S}$ promoter using the pCAMBIA1302 binary vector and used these plasmids to transform Arabidopsis. Transgenic $C D D$ plants showed midget (dwarfism) phenotypes and formed disease-like necrotic lesions on their leaves (Figure 9b and c). These phenotypes are highly similar to those of Arabidopsis mutants such as acd1 (accelerated cell death), cpr1 (constitutive expressor of PR genes), Isd1 (lesion stimulating disease 1), and agd2 (aberrant growth and death 2 ), which display a constitutive pathogen response. ${ }^{44-47}$ Untransformed wild-type, vector control, and $C D D^{15755}$ transgenic plants grown under identical conditions did not show these phenotypes (Figure 9). CDD and CDD ${ }^{1575}$ proteins were detected immunologically in transgenic lines transformed with $C D D$ and $C D D^{1157 S}$ constructs. These proteins were not detected in either wild-type or control plants (Figure 9a).

Plant cells undergoing hypersensitive response (HR)-cell death, which is known to occur via PCD, deposit cell wall materials including callose and aromatic polymers at their infected sites. ${ }^{46,48}$ To determine whether the cell death (Figure 9c) found in transgenic lines expressing $C D D$ involved HR-like lesions, plants were stained for callose with aniline blue and observed under fluorescence microscopy

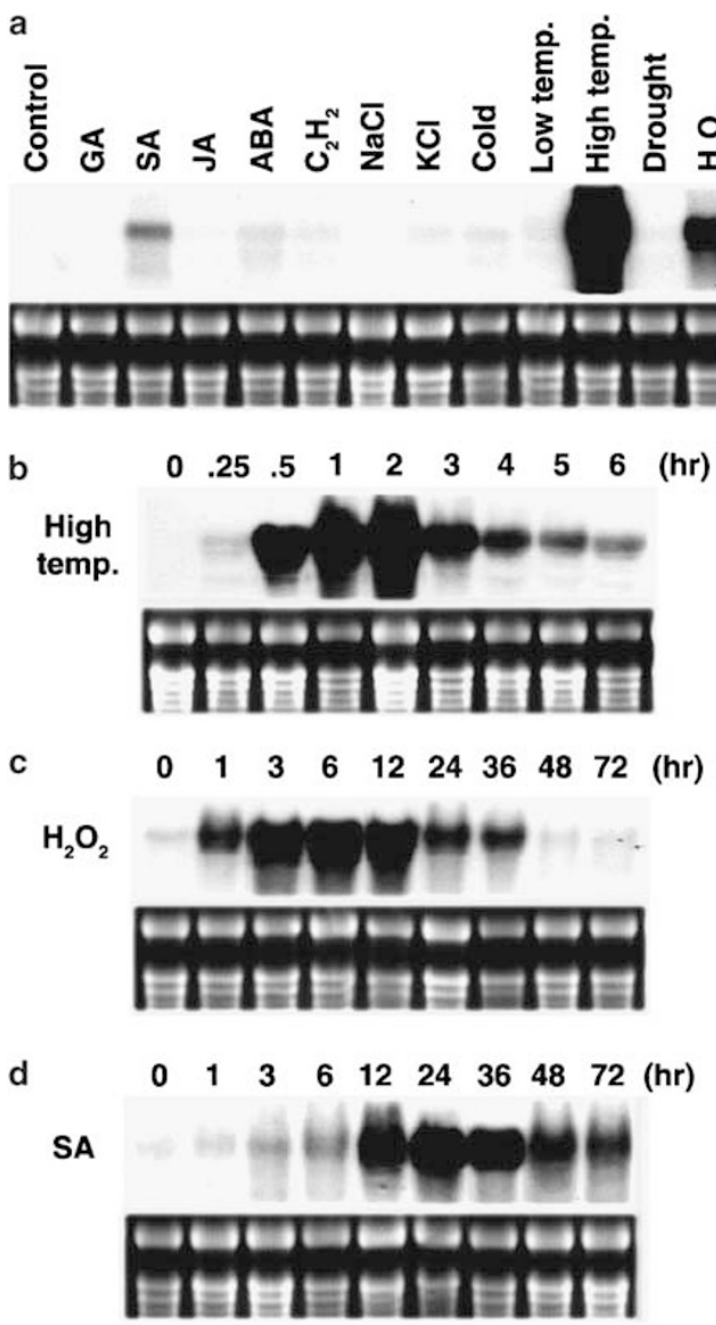

Figure 8 AtBAG6 transcripts accumulate during the stress response. (a) Total RNA was prepared from 4-week-old Arabidopsis whole plants treated with several chemicals $\left(0.1 \mu \mathrm{M} \mathrm{GA}_{4}, 2 \mathrm{mM} \mathrm{SA}, 100 \mu \mathrm{M} \mathrm{JA}, 100 \mu \mathrm{M}\right.$ ABA, $5 \mathrm{mM}$ 2chloroethylphosphonic acid, $100 \mathrm{mM} \mathrm{NaCl}, 100 \mathrm{mM} \mathrm{KCl}$, or $2 \mathrm{mM} \mathrm{H}_{2} \mathrm{O}_{2}$ ) or environmental stress (cold; $4^{\circ} \mathrm{C}$ for $6 \mathrm{~h}$, low temperature; $15^{\circ} \mathrm{C}$ for $12 \mathrm{~h}$, high temperature; $37^{\circ} \mathrm{C}$ for $6 \mathrm{~h}$ or drought). A fixed amount of total RNA $(20 \mu \mathrm{g})$ was loaded onto each lane. Equal loading for each lane was confirmed by staining gels with ethidium bromide (lower). An RNA blot was prepared with ${ }^{32} \mathrm{P}$-labeled AtBAG6 cDNA. (b) Effect of high temperature on AtBAG6 expression. Arabidopsis whole plants (4 weeks old) were incubated at $37^{\circ} \mathrm{C}$ for the indicated times, and total RNA samples were prepared for Northern blot analysis. (c) Effect of $\mathrm{H}_{2} \mathrm{O}_{2}$ on AtBAG6 expression. Arabidopsis whole plants (4 weeks old) were treated with $\mathrm{H}_{2} \mathrm{O}_{2}(2 \mathrm{mM})$ for the indicate time. (d) Effect of $\mathrm{SA}$ on the expression of AtBAG6. Arabidopsis whole plants (4 weeks old) were treated with SA (2 mM) for the indicated times

(Figure 9d). Whole-mount leaves of $C D D$ transgenic plants showed prominent abundance of callose, whereas wild-type, control, and $C D D^{1575 S}$ transgenic plants did not (Figure 9d). Taken together, these results indicate that these necrotic lesions resemble HR-like lesions.

\section{Discussion}

In this report, we present biochemical and functional data in support of a role for AtBAG6, a BAG domain protein from 

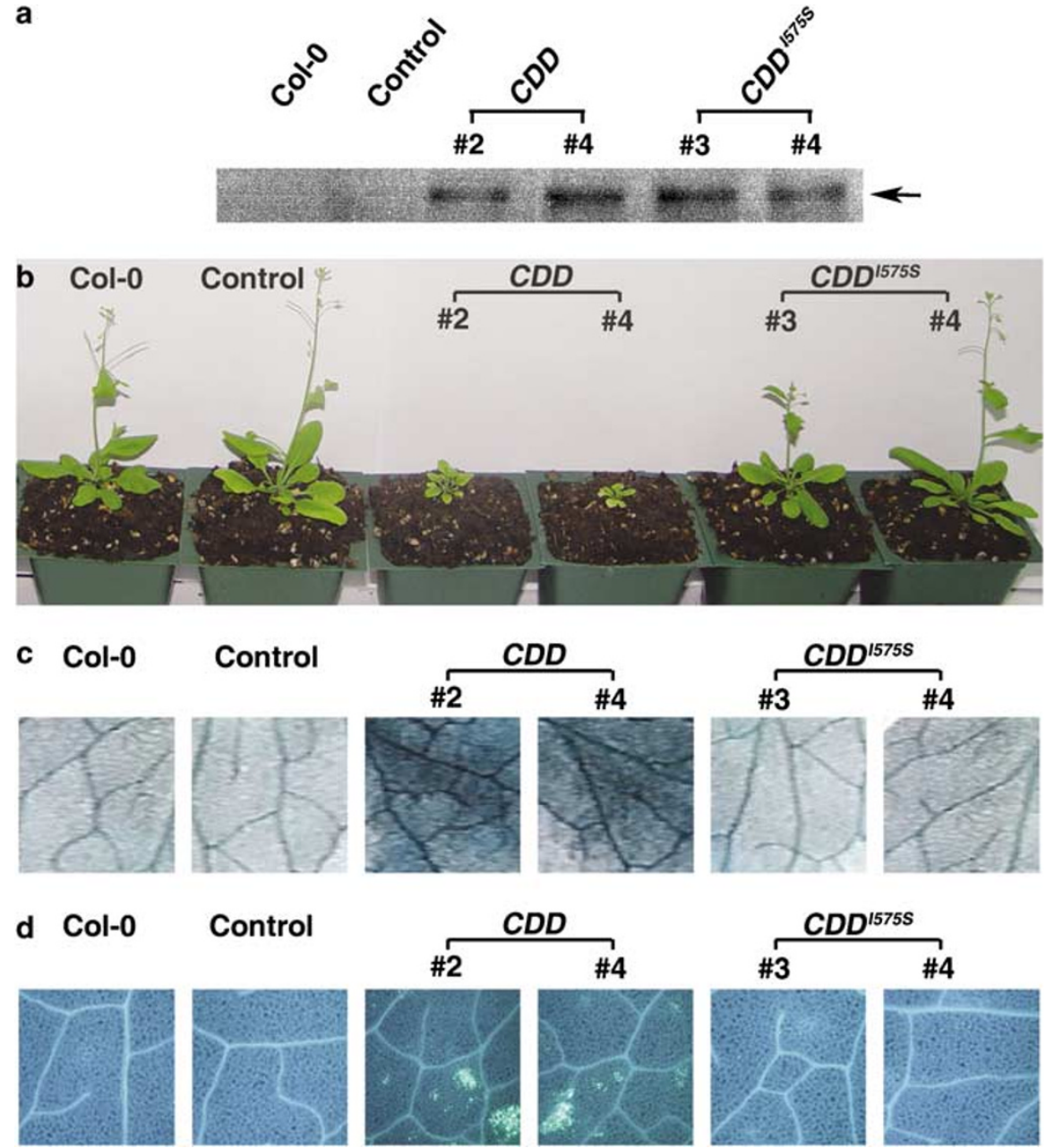

Figure 9 Phenotypes associated with the expression of $C D D$ and $C D D^{1575 s}$ in plants. (a) Immunological detection of the 6-His fused $C D D$ and $C D D^{15755}$ proteins. The functionalities of these constructs were firstly confirmed in yeast (Figure 5 and data not shown). In all, $40 \mu \mathrm{g}$ of total proteins from plants shown in (b) were used for Western blot analysis using anti-His tag antibody conjugated with horseradish peroxidase. The arrow indicates the predicted size of the produced proteins. Col-0, wildtype plant; Control, transgenic plant transformed vector alone; $C D D$, transgenic plants transformed with $C D D$ (representative lines, \#2, \#4 were indicated); $C D D^{15755}$ transgenic plants transformed with $C D D^{1575 S}$ (representative lines, \#3, \#4 were indicated). (b) Phenotypes associated with expression of CDD in transgenic Arabidopsis. Photographs were taken 5 weeks after sowing. Lactophenol-trypan blue (c) and aniline blue staining (d) was performed as described in Materials and Methods using the plants shown in (b)

Arabidopsis, in CaM-mediated cell death. We demonstrate that (i) oxidative stress, involved in plant PCD processes, ${ }^{40-43}$ induces the transient expression of AtBAG6, (ii) AtBAG6 physically interacts with AtCaMs, (iii) the IQ motif in the AtBAG6 is required for $\mathrm{Ca}^{2+}$-independent $\mathrm{CaM}$ complex formation, and (iv) the CaM-binding IQ motif and BAG domain are required for AtBAG6-mediated cell death in both yeast and plant. In animals, $\mathrm{Ca}^{2+}$ released into the cytoplasm can induce mitochondrial permeability transition (PT) pore opening, which induces release of apoptotic activators to the cytoplasm and consequently activates caspase-mediated PCD. $^{49,50}$ Although mechanisms and regulation of plant PCD are ill-defined, experimental evidences indicate that $\mathrm{Ca}^{2+}$ fluxes have pivotal role in the processes. Included are self-incompatibility of pollen, aleurone differentiation, aerenchyma formation, $\mathrm{HR}$ and leaf senescence. ${ }^{51-54}$ Additional data confirm a role of CaMBP or channel in pathogen defense. The Arabidopsis Dnd1 gene, that encodes a cyclic nucleotidedependent calcium channel, is required for the activation of
HR-induced cell death. ${ }^{55}$ Although the mechanism by which the CaM-AtBAG6 complex interacts and functions together with downstream components in planta is currently unclear, our observations suggest that AtBAG6 may be a specific component of $\mathrm{Ca}^{2+} / \mathrm{CaM}$-mediated PCD process in plants.

We screened an Arabidopsis expression library with $\mathrm{CaM}:: \mathrm{HRP}$, and identified a novel CaM-binding protein, AtBAG6. Based on the structural characteristics of known CaMBDs, the CaM-binding IQ motif was localized to the middle region of AtBAG6 between Ala $^{572}$ and Lys ${ }^{591}$ (Figure 1). This prediction was confirmed by the CaM::HRP overlay assay (Figures 2 and 3). 'Complete IQ motifs' (containing the $\mathrm{G}$ and a second basic residue) do not require $\mathrm{Ca}^{2+}$-binding to CaM, whereas 'incomplete IQ motifs' (lacking the second basic residue) are $\mathrm{Ca}^{2+}$-dependent. ${ }^{56,57}$ Within the 20 amino-acid stretch (from Ala ${ }^{572}$ to Lys ${ }^{591}$ ) of AtBAG6 (Figure 1), the conserved residues, the first hydrophobic residue (preceding $\left.\mathrm{Q}, 11 \mathrm{e}^{575}\right), \mathrm{Q}\left(\mathrm{G} \mid \mathrm{n}^{576}\right)$, and the first basic residue $\left(\mathrm{Arg}^{580}\right)$ are present. Furthermore, $\mathrm{G}\left(\mathrm{Gly}{ }^{581}\right)$ 
and the second basic residue $\left(\mathrm{Arg}^{585}\right)$ are observed. These features of CaMBD in AtBAG6 are characteristic of the complete consensus IQ motif. ${ }^{56}$ Consistent with these finding, our data confirm that AtBAG6 binds CaM in a $\mathrm{Ca}^{2+}$. independent manner.

In mammals, some BAG domain proteins regulate diverse cellular functions by interacting with HSP70/HSC70 and modulating its activity. For example, the regulation of HSP70/HSC70 activity by BAG-1 M has been extensively studied in animals. A number of reports demonstrated that $\mathrm{Glu}^{212}$, Asp ${ }^{222}$, Lys ${ }^{238}$, and GIn ${ }^{245}$ of BAG-1 are crucial for these interactions. ${ }^{58,59}$ However, when we performed either yeast two-hybrid or in vitro binding assays, we failed to detect any interactions between AtBAG6 and AtHSC70 (Figure 7 and data not shown). These results suggest that modulation of HSP70/HSC70 activity is not a universal function of BAG domain proteins. However, we still cannot rule out the possibility that AtBAG6 interacts with $\mathrm{HSP} 70 / \mathrm{HSC} 70$ in vivo or that some other factors or specific conditions are required for this interaction.

Recent studies suggest that the BAG proteins regulate diverse biochemical events, including receptor signaling, protein kinase, and transcription factor activity, thereby affect diverse cellular behaviors ranging from cell division and differentiation to cell death. ${ }^{60-69}$ The functional diversity of BAG domain proteins is paralleled by an abundance of genes of this family throughout evolution, with homologs identified in a variety of organisms, including yeast, worm, invertebrates, amphibians, mammals, and plants. ${ }^{21,59,60,70}$ Database searches indicate the presence of eight genes that encode proteins with the BAG domain in Arabidopsis thaliana. ${ }^{28}$ Among the proteins encoded by these genes, four (AtBAG5, AtBAG6, AtBAG7, and AtBAG8) contain a CaMBD (IQ motif) close to the conserved BAG domain. They might be functionally redundant since two T-DNA-inserted AtBAG6 mutant lines did not show any significant phenotypic differences under several stress conditions (heat, cold, salt, UV, light, or dark) (data not shown). Another possibility is that they have distinct functions reflected by different spatial and temporal regulation. ${ }^{71,72}$ It would be of interest to investigate the spatial and temporal regulation of AtBAG6 paralogues to elucidate their specific molecular functions.

Biotic stress-mediated cell death processes, such as HR, are known to exhibit morphological and biochemical hallmarks of PCD in mammalian systems. Moreover, since PCD in plants has been recognized as an integral component of an adaptive mechanism to stress, scientific opinion on abiotic stress-mediated cell death has recently shifted. ${ }^{52}$ Abiotic stresses, including temperature, salinity, drought, light, ROS, and ozone, are now often regarded not as toxins, but rather as elicitors of PCD, when plant cells are chronically exposed to physiological levels of these stresses. ${ }^{41,73-77}$ However, necrosis, which represents an uncontrolled form of cell death, does occur in plant cells when they are exposed to high levels of abiotic stress that the plant cannot override with their tolerance mechanisms. ROS are pivotal mediators of PCD in plants. ROS are utilized as second messengers in the execution of cell death during hypersensitivity responses and ozone-mediated cell death - well-studied plant PCD phenomenona that are induced by biotic and abiotic stress, respectively. ${ }^{42}$ Similarly, AtBAG6-induced cell death in Arabidopsis and yeast is also mediated by ROS generation (Figures 4 and 8). Therefore, it would appear that ROS is a common element and key event of PCD in animals, plants, and yeast, where it is a common component of a basic, evolutionarily conserved mechanism.

It has been reported that the expression of $B A X$ (a mammalian proapoptotic member of the BCL2 family) in yeast and plants induces apoptosis. ${ }^{78}$ Although informatics has failed to identify BAX, BCL2, and BCLX $X_{L}$ sequence homologs in either the Arabidopsis or yeast (Saccharomyces cerevisiae) genomes, there is evidence that the basic regulatory mechanisms underlying $P C D$ are conserved in animal and plant systems. ${ }^{79,80}$ Experimental evidence of these conserved mechanisms include caspase-like activities detected in various plant cell-death model systems, the demonstration that expression of animal $B A X$ can induce $P C D$ in plants and yeast, and the identification of the plant BAX inhibitor-1 (BI-1) that can suppress cell death in both plants and animals. These strands of evidence indicate the existence of functional orthologs of BCL2, and its interacting proteins, in plants. Further identification of components associated with the CaM-AtBAG6-mediated cellular response should facilitate elucidation of the mechanism(s) by which AtBAG6 regulates cell death.

\section{Materials and Methods}

\section{Screening of the Arabidopsis cDNA expression library}

A cDNA expression library in a $\lambda$ ZAPII vector (Stratagene, La Jolla, CA, USA) was constructed with RNA from 4-week-old $A$. thaliana (ecotype Columbia) plants that were treated with heat shock $\left(37^{\circ} \mathrm{C}\right)$ for $2 \mathrm{~h}$. Subsequently, it was screened using horseradish peroxidase (HRP)conjugated Arabidopsis calmodulin-2 (AtCaM2::HRP) as a probe. AtCaM2 was conjugated to maleimide-activated HRP using the EZ-Link maleimideactivated HRP conjugation kit (Pierce, Rockford, IL, USA), as described in a previous report. ${ }^{81}$ Approximately $5 \times 10^{5}$ pfu cells were plated per $15 \mathrm{~cm}$ LB plate, using E. coli XL1-blue MRF (Stratagene, La Jolla, CA, USA) as the host strain. Plates were incubated at $42^{\circ} \mathrm{C}$ until plaques appeared, and overlaid with nitrocellulose filters previously soaked in $10 \mathrm{mM}$ IPTG. Incubation was continued at $37^{\circ} \mathrm{C}$ for $6-8 \mathrm{~h}$, and plates were cooled to $4^{\circ} \mathrm{C}$. Filters were removed, and rinsed twice in a large volume of TBS-T (Tris-based saline containing $0.1 \%(\mathrm{v} / \mathrm{v})$ Tween-20). Next, filters were blocked by incubation in $7 \%(\mathrm{w} / \mathrm{v})$ nonfat dry milk/TBS-T overnight. Blocked filters were washed three times with TBS-T for $5 \mathrm{~min}$ and equilibrated in overlay buffer ( $50 \mathrm{mM}$ imidazole-HCl $(\mathrm{pH} 7.5), 150 \mathrm{mM}$ $\mathrm{NaCl}$ ) for $1 \mathrm{~h}$. Membranes were blocked secondly by incubating filters in overlay buffer containing $9 \%(\mathrm{v} / \mathrm{v})$ gelatin (Sigma-Aldrich, St. Louis, MO, USA), $0.5 \%$ (v/v) Tween-20, and 5 mM EGTA for $3.5 \mathrm{~h}$. AtCaM2::HRP was added to gelatin-containing buffer at a final concentration of $0.2 \mu \mathrm{g} / \mathrm{ml}$, and filters were incubated for $1 \mathrm{~h}$. The final washing was performed in three steps, with each step consisting of five repeats of a 5-min wash: firstly in TBS-T/50 mM imidazole- $\mathrm{HCl}(\mathrm{pH} 7.5)$ and $5 \mathrm{mM}$ EGTA; secondly in $20 \mathrm{mM}$ Tris- $\mathrm{HCl}(\mathrm{pH} 7.5), 0.5 \%$ Tween-20, $50 \mathrm{mM}$ imidazole- $\mathrm{HCl}, 0.5 \mathrm{M}$ $\mathrm{KCl}$, and $5 \mathrm{mM}$ EGTA; and thirdly in $20 \mathrm{mM}$ Tris- $\mathrm{HCl}(\mathrm{pH} 7.5), 0.1 \%$ Tween-20, and $1 \mathrm{mM} \mathrm{MgCl}$. Bound AtCaM2::HRP was visualized using an enhanced chemiluminescence (ECL) detection kit (Amersham Pharmacia Biotech, Uppsala, Sweden). A total of $5 \times 10^{5}$ recombinants 
were screened, and 11 positive clones isolated after three rounds of screening. cDNA inserts were recovered by in vivo excision with helper phage (ExAssist, Stratagene, La Jolla, CA, USA). To confirm binding to AtCaM2, we expressed positive clones as $\beta$-galactosidase fusion proteins in E. coli. Clones were examined for CaM-binding by AtCaM2::HRP overlay assay, as described above. In brief, we transformed positive clones into $E$. coli XL1-blue MRF and induced the expression of $\beta$-galactosidase fusion proteins by treatment with $0.5 \mathrm{mM}$ IPTG. IPTGinduced $E$. coli crude proteins $(20 \mu \mathrm{g})$ were separated on a $10 \%$ SDSpolyacrylamide gel, and transferred to an Immobilon-MP membrane (PVDF, Millipore, Bedford, MA, USA). The membrane was rinsed in TBST, blocked by incubation in $7 \%$ (w/v) nonfat dry milk/TBS-T overnight, and processed as described above. For determination of $\mathrm{Ca}^{2+}$-dependent binding of $\mathrm{CaM}, 1 \mathrm{mM} \mathrm{CaCl}_{2}$ was substituted for $5 \mathrm{mM} \mathrm{EGTA}$ in all overlay buffers. The cDNA sequences of the resulting positive clones were determined from both strands by dideoxynucleotide chain termination using an automatic DNA sequencer (ABI 373A, Applied Biosystems, Foster City, CA, USA).

\section{Yeast two-hybrid assays}

The full-length coding region of AtBAG6 was cloned into the pGBT9 vector (encoding the TRP1 gene, Clontech, Palo Alto, CA, USA) containing the GAL4 DNA-binding domain (BD). An Arabidopsis cDNA library was constructed into the $p G A D 424$ vector (including the LEU2 gene, Clontech, Palo Alto, CA, USA) containing the GAL4 activation domain (AD). pTD1-1 and pVA3-1 (Clontech, Palo Alto, CA, USA) encoding the interacting proteins, tumor suppressor $\mathrm{p} 53$ and simian virus 40 (SV40) large Tantigen fused to $B D$ and $A D$, respectively, were used as positive controls. $^{82}$ The $p G A D 424$ vector containing the Arabidopsis cDNA library was transformed into the yeast reporter strain pJ69-4A (MATa trp1-90 leu2-3,112 ura3-52 his3-200 gal4 $\Delta$ gal80 $\Delta$ LYS2::GAL1-HIS3 GAL2ADE2 met2::GAL7-lacZ) harboring pGBT9-AtBAG6. ${ }^{83}$ Interactions between the encoded fusion proteins were investigated by cotransforming appropriate plasmids into the yeast strain pJ69-4. Transformed yeast cells bearing both the plasmids were selected by plating on SD medium $(0.67 \%$ nitrogen base without amino acids, amino acids and nucleotide bases) lacking tryptophan and leucine (SD-WL), and grown at $30^{\circ} \mathrm{C}$ for 4 days. We tested the interactions of proteins encoded by recombinant $p G B T 9$ / pGAD424 by growing cells in SD medium lacking tryptophan, leucine, and adenine (SD-WLA). Adenine-positive colonies were further tested for $\beta$ galactosidase ( $L a C Z$ ) activation, according to the manufacturer's protocol (Clontech, Palo Alto, CA, USA).

\section{Construction of deletion mutants of AtBAG6 cDNA and site-directed mutagenesis}

For mapping of the CaM-binding domain, several fragment constructs were generated in a $p G E X-5 X-2$ vector (Amersham Pharmacia Biotech, Uppsala, Sweden). To observe the phenotypes of yeast cells overexpressing several genes, we used $p Y E S 2-G S T$ fusion vector, which had been derived from pYES2 vector (Invitrogen, Carlsbad, CA, USA). A Kpnl$B a m H I$ fragment has been amplified by polymerase chain reaction (PCR) with $p G E X-5 X-2$ vector as template and primers designed to amplify the vector residues $258-940$, which encode the $26 \mathrm{kDa}$ glutathione Stransferase (GST). The fragment was inserted into a pYES2 vector digested with Kpnl and BamHI to produce the pYES2-GST fusion vector.

The full-length AtBAG6 CDNA clone was amplified by PCR with a forward $\left(5^{\prime}\right)$ primer containing a Bgll site $\left(5^{\prime}\right.$-AGATCTTAAT GATGCCTGTGTACATGGA-3 $3^{\prime}$ ) and a reverse $\left(3^{\prime}\right)$ primer containing a Xhol site (5'-CCTCGAGGTCATAATACGGCATCGGT-3'). The PCR product was cloned into the pGEM-T vector (Promega, Madison, WI, USA) and sequenced to verify the correct construct. The construct was digested with Bgll and Xhol and subcloned into the pGEX-5X-2 expression vector digested with BamHI and Xhol. This full-length GSTfusion construct was designated D0 (encompassing amino acids 1-1043). To analyze the regions to bind CaM or to induce cell death in yeast, serial fragment constructs additionally generated by PCR using the following forward $(F)$ and reverse $(R)$ primer sequences: for D1 (amino acids 1579): $F$, containing a Bgll site (5'-AGATCTTAATGATGCCTGTGTA CATGGA-3') and R, containing a Xhol site (5'-CATCTCGAGGCTACA TAGATTG-3'); for D2 (amino acids 1-592): F, containing a Bgll site $\left(5^{\prime}\right.$ AGATCTTAATGATGCCTGTGTACATGGA-3') and R, containing a Xhol site (5'-CTCGAGCAATTACTTAATTGG-3'); for D3 (amino acids 5601043): F, containing a BamHI site (5'-GGAGAATGGATCCAGCCTGC- $3^{\prime}$ ) and $R$, containing a Xhol site (5'-CCTCGAGGTCATAATACGG CATCGGT-3'); for D4 (amino acids 584-1043): F, containing a BamHI site ( $5^{\prime}$-GTACCGTGGATCCACGTGAGAAG-3') and R, containing a Xhol site (5'-CCTCGAGGTCATAATACGGCATCGGT-3'); for CDD (amino acids 560-693): F, containing a BamHI site (5'-GGAGAATGGATC CAGCCTGC- $\left.3^{\prime}\right)$ and $\mathrm{R}$, containing a Xhol site (5'- CCTCGAGAGGCT GAGATTTAATTTCCAC- $\left.3^{\prime}\right)$. The amplified products were cloned into the pGEM-T vector, and subcloned into the pGEX-5X-2 expression vector digested with BamHI and Xhol for E. coli or pYES2-GST fusion vector digested with BamHI and Xhol for yeast.

To identify the critical residues in the interactions between CaM and AtBAG6, we introduced several point mutations into the IQ motif of CDD (CaMBD). Substitution of single amino acids was performed using the QuickChangeTM Site-Directed Mutagenesis Kit (Stratagene, La Jolla, CA, USA). The following $F$ and $R$ primers were employed: for I575V: $F, 5^{\prime}$ GCTAGAATTGTCCAATCTATG-3' and R, 5'-CATAGATTGGACAATTC TAGC-3'; for I575S: F, 5' -GCTAGAATTAGCCAATCTATG-3' and R, 5'CATAGATTGGCTAATTCTAGC-3'; for I575N: F, 5'-GCTAGAATTAA CCAATCTATG- $3^{\prime}$ and R, 5'-CATAGATTGGTTAATTCTAGC-3'.

\section{Production of recombinant proteins in E. coli and the CaM-binding assay}

All clones were introduced into E. coliBL21(DE3)pLysS. Production of the 6-His tag fusion or GST fusion proteins was induced by the application of $1 \mathrm{mM}$ IPTG for $5 \mathrm{~h}$ at $25^{\circ} \mathrm{C}$. Cells were harvested, resuspended in lysis buffer (50 mM Tris-HCl (pH 7.5), 2 mM PMSF, $1 \mathrm{mM} \mathrm{DTT,} 100 \mu \mathrm{g} / \mathrm{ml}$ lysozyme), and incubated on ice for $20 \mathrm{~min}$. The mixture was sonicated for $1 \mathrm{~min}$ at $50 \%$ pulse and centrifuged at $6000 \times g$ for $10 \mathrm{~min}$ to remove cell debris. The supernatant (containing the $E$. coli crude protein) was used for Western blotting and AtCaM2::HRP gel overlay assay. E. coli crude protein $(20 \mu \mathrm{g})$ was separated on $10 \%$ SDS-polyacrylamide gels, and transferred to Immobilon-P membranes (PVDF, Millipore, Bedford, MA, USA). Expressed 6-His tag fusion or GST fusion proteins were detected with the appropriate specific antisera. For far-Western blotting, the 6-His tag was detected by His-probe::HRP (Santa Cruz Biotechnology, CA USA). ${ }^{84}$ To determine the CaM-binding abilities of recombinant proteins, a duplicate blot was probed with an AtCaM2::HRP conjugate in the presence of $5 \mathrm{mM}$ EGTA or $1 \mathrm{mM} \mathrm{CaCl}$. The AtCaM2::HRP overlay assay was performed as described above. Bound $\mathrm{CaM}$ was visualized using an ECL detection system (Amersham Pharmacia Biotech, Uppsala, Sweden).

\section{Yeast strains, spot assay, and viability assay}

Plasmids containing full-length AtBAG6 or a serial fragment were cloned into the $p Y E S 2-G S T$ fusion vector, as described above. Additionally $B A X$, AtBAG1, and AtBAG8 genes were cloned by PCR and subcloned into 
pYES2-GST. The plasmids were transformed into the wild-type $S$. cerevisiae strain, W303-1a (MATa ura3-1, leu2-3, 112 his3-11, 15 ade2-1 trp 1-1 can1-110). ${ }^{85}$ For spot assays, strains were pregrown in SD medium lacking uracil in the presence of $2 \%$ glucose as the carbon source (SD-U/ Glu) at $30^{\circ} \mathrm{C}$ to a cell density of about $0.5 \times 10^{6} / \mathrm{cm}^{3}$. After washing three times, aliquots $(10 \mu \mathrm{l})$ of 10 -fold serial dilutions were spotted on plates of SD medium lacking uracil, in the presence of $2 \%$ glucose (SD-U/Glu) or $2 \%$ galactose (SD-U/Gal) as the carbon source. Plates were incubated at $30^{\circ} \mathrm{C}$, and examined for surviving cells after 4 days.

To determine the viabilities of strains, cells were pregrown in SD medium lacking uracil, and containing $2 \%$ glucose (SD-U/Glu) as described above, and pelleted by centrifugation $(1000 \times g)$ for $10 \mathrm{~min}$. After washing three times, cells were resuspended in $10 \mathrm{ml} \mathrm{SD}$ medium lacking uracil in the presence of $2 \%$ galactose (SD-U/Gal) to an optical density at $600 \mathrm{~nm}\left(\mathrm{OD}_{600}\right)$ of 1.3 . After culturing for various times (0-24 days), the optical densities of media at $600 \mathrm{~nm}\left(\mathrm{OD}_{600}\right)$ were measured after four-fold dilution. Aliquots of cells were plated on SD medium lacking uracil in the presence $2 \%$ glucose (SD-U/Glu). Plates were incubated at $30^{\circ} \mathrm{C}$ for 4 days, and the numbers of colonies were counted.

\section{Microscopic examination}

For microscopic examination, strains were pregrown in SD medium lacking uracil and containing $2 \%$ glucose (SD-U/Glu), as described above. After washing three times, cells were cultured in SD medium lacking uracil in the presence of $2 \%$ galactose (SD-U/Gal) for $12 \mathrm{~h}$. TdT-mediated dUTP nick end labeling (TUNEL) tests were performed with the In Situ Cell Death Detection Kit, Fluorescein (Roche Applied Science, Indianapolis, IN, USA) as described by Madeo et al. ${ }^{38}$ Phosphatidylserine exposure was detected by an FITC-coupled annexin $\mathrm{V}$ reaction with the ApoAlert Annexin $\mathrm{V}$ Apoptosis kit (Clontech, Palo Alto, CA, USA), essentially as described by Ludovico et al. ${ }^{34}$ To visualize nuclei, cells were incubated with $1 \mu \mathrm{g} / \mathrm{ml}$ DAPI in HEPES buffer (10 mM HEPES/ $\mathrm{NaOH}$ buffer $\mathrm{pH} 7.4,140 \mathrm{mM}$ $\mathrm{NaCl}, 2.5 \mathrm{mM} \mathrm{CaCl}_{2}$ ) for $20 \mathrm{~min}$, washed three times with HEPES buffer, and examined under a fluorescence microscope. To determine ROS generation, cells were rewashed in water, resuspended in Tris buffer ( $50 \mathrm{mM}$ Tris- $\mathrm{HCl}, \mathrm{pH} 7.5$ ), incubated for $2 \mathrm{~h}$ at room temperature with $5 \mu \mathrm{g} /$ $\mathrm{ml}$ dihydrorhodamine123 (Molecular Probes, Eugene, OR, USA), and examined under a fluorescence microscope. ${ }^{85}$

\section{Northern blot analysis}

Whole Arabidopsis plants (4 weeks old) were treated with several chemicals $\left(0.1 \mu \mathrm{M} \mathrm{GA}_{4}, 2 \mathrm{mM}\right.$ SA, $100 \mu \mathrm{M} \mathrm{JA}, 100 \mu \mathrm{M}$ ABA, $5 \mathrm{mM}$ 2chloroethylphosphonic acid, $100 \mathrm{mM} \mathrm{NaCl}, 100 \mathrm{mM} \mathrm{KCl}, 2 \mathrm{mM} \mathrm{H}_{2} \mathrm{O}_{2}$ ) and environmental stress conditions (cold; $4^{\circ} \mathrm{C}$ for $6 \mathrm{~h}$, low temperature; $15^{\circ} \mathrm{C}$ for $12 \mathrm{~h}$, high temperature; $37^{\circ} \mathrm{C}$ for $6 \mathrm{~h}$ and drought).

Total RNA was isolated by phenol/chloroform extraction, followed by lithium chloride precipitation. ${ }^{86}$ RNA $(20 \mu \mathrm{g})$ was denatured, separated by electrophoresis on a $1.2 \%(\mathrm{w} / \mathrm{v})$ agarose-formaldehyde gel, and transferred to a nylon membrane (GeneScreen Plus, PerkinElmer Life and Analytical Sciences, Boston, MA, USA). Membranes were incubated with ${ }^{32} \mathrm{P}$-labeled full-length $A t B A G 6 \mathrm{cDNA}$ at $65^{\circ} \mathrm{C}$ overnight, and washed under high stringency conditions according to the method of Church and Gilbert. $^{87}$

\section{Construction of transgenic plants and tests for PCD}

For experiments with Arabidopsis, A. thaliana (ecotype Columbia) was used. The plants were grown on a solid medium containing basic MS salts
(Duchefa Biochemical Co., Netherlands), 3\% sucrose, and 0.8\% agar. To generate overexpressing transgenic lines, we cloned full-length AtBAG6, $C D D$ or $C D D^{1575 S}$ which had been N-terminally fused to GST coding region downstream of the cauliflower mosaic virus 35S promoter, in the sense orientation into the $P C A M B I A 1302$ binary vector. For control lines, only an empty vector construct was used. These plasmid constructs were first transformed into Agrobacterium tumefaciens GV3101 and then subsequently into Arabidopsis wild-type (Col-0) backgrounds. Kanamycin was used for bacterial selection and hygromycin B for plant selection. Plants of the T0 generation were grown to maturity and T1 seeds were harvested. T1 progeny of transgenic plants expressing high levels of GST-CDD or GST-CDD ${ }^{1575 S}$ were used for all of the experiments. For the PCD experiments, 2-week-old seedlings on solid agar plates containing $30 \mu \mathrm{g} / \mathrm{ml}$ hygromycin B were transferred to soil and maintained at $22^{\circ} \mathrm{C}$ under long-day conditions ( $16 \mathrm{~h}$ light/8 $\mathrm{h}$ dark). After growth for 4 weeks on soil, the fourth leaves were detached and were tested for PCD. Cell death was detected by lactophenol-trypan blue staining as described by Koch and Slusarenko. ${ }^{88}$ For aniline blue staining of callose, plant samples were boiled in ethanol/lactophenol $(2: 1(\mathrm{v} / \mathrm{v}))$ for $20 \mathrm{~min}$. Samples were then rinsed with water to remove the lactophenol and stained for $1 \mathrm{~h}$ with aniline blue $(0.01 \%$ aniline blue powder in $150 \mathrm{mM}$ $\mathrm{K}_{2} \mathrm{PO}_{4}, \mathrm{pH}$ 9.5). Before samples were mounted, they were equilibrated in $50 \%$ glycerol. Aniline blue staining was visualized by fluorescence microscopy. ${ }^{89}$

\section{Acknowledgements}

This research was partially supported by grants (PF0330401-00) from the Plant Diversity Research Center of the 21st Century Frontier Research Program, MOST, the Environmental Biotechnology Core Research Center (R15-2003-012-01002-0) from KOSEF/MOST, KRIBB Research initiative program, and Bigreen 21 program, Rural Development Administration, Korea. CH Kang, WY Jung, JC Jeong, DW Baek were supported by scholarships from the Brain Korea 21 program, Ministry of Education, Korea.

\section{References}

1. McAinsh MR and Hetherington AM (1998) Encoding specificity in $\mathrm{Ca}^{2+}$ signalling systems. Trends Plant Sci. 3: $32-36$

2. Trewavas AJ and Malho RC (1998) $\mathrm{Ca}^{2+}$ signalling in plant cells: the big network!. Curr. Opin. Plant Biol. 1: 428-433

3. Dolmetsch RE, Lewis RS, Goodnow CC and Healy JI (1997) Differential activation of transcription factors induced by $\mathrm{Ca}^{2+}$ response amplitude and duration. Nature 386: 855-858

4. Snedden WA and Fromm $\mathrm{H}$ (2001) Calmodulin as a versatile calcium signal transducer in plants. New Phytol. 151: 35-66

5. Hoeflich KP and Ikura M (2002) Calmodulin in action: diversity in target recognition and activation mechanisms. Cell. Cell 108: 739-742

6. Yokouchi T, Izumi Y, Matsufuji T, Jinbo Y and Yoshino H (2003) Unfolding intermediate of a multidomain protein, calmodulin, in urea as revealed by smallangle X-ray scattering. FEBS Lett. 551: 119-122

7. Alexander KA, Wakim BT, Doyle GS, Walsh KA and Storm DR (1988) Identification and characterization of the calmodulin-binding domain of neuromodulin, a neurospecific calmodulin-binding protein. J. Biol. Chem. 263: 7544-7549

8. Baudier J, Deloulme JC, Van Dorsselaer A, Black D and Matthes HW (1991) Purification and characterization of a brain-specific protein kinase $C$ substrate, neurogranin ( $p 17)$. Identification of a consensus amino acid sequence between neurogranin and neuromodulin (GAP43) that corresponds to the protein kinase 
C phosphorylation site and the calmodulin-binding domain. J. Biol. Chem. 266 229-237

9. Mitchell EJ, Karn J, Brown DM, Newman A, Jakes R and Kendrick-Jones J (1989) Regulatory and essential light-chain-binding sites in myosin heavy chain subfragment-1 mapped by site-directed mutagenesis. J. Mol. Biol. 208: 199205

10. McNally EM, Bravo-Zehnder MM and Leinwand LA (1991) Identification of sequences necessary for the association of cardiac myosin subunits. J. Cell. Biol. 113: 585-590

11. Kiegle E, Moore CA, Haseloff J, Tester MA and Knight MR (2000) Cell-typespecific calcium responses to drought, salt and cold in the Arabidopsis root. Plant J. 23: 267-278

12. Knight $\mathrm{H}(2000)$ Calcium signaling during abiotic stress in plants. Int. Rev. Cytol. 195: 269-324

13. Zielinski RE (1998) Calmodulin and calmodulin-binding proteins in plants. Annu. Rev. Plant Physiol. Plant Mol. Biol. 49: 697-725

14. Reddy VS, Ali GS and Reddy AS (2002) Genes encoding calmodulin-binding proteins in the Arabidopsis genome. J. Biol. Chem. 277: 9840-9852

15. Yang $T$ and Poovaiah BW (2003) Calcium/calmodulin-mediated signal network in plants. Trends Plant Sci. 8: 505-512

16. Takayama S, Sato T, Krajewski S, Kochel K, Irie S, Millan JA and Reed JC (1995) Cloning and functional analysis of BAG-1: a novel Bcl-2-binding protein with anti-cell death activity. Cell 80: 279-284

17. Takayama S, Xie Z and Reed JC (1999) An evolutionarily conserved family of Hsp70/Hsc70 molecular chaperone regulators. J. Biol. Chem. 274: 781-786

18. Doong $H$, Vrailas A and Kohn EC (2002) What's in the 'BAG' ? - A functional domain analysis of the BAG-family proteins. Cancer Lett. 188: 25-32

19. Hung WJ, Roberson RS, Taft J and Wu DY (2003) Human BAG-1 proteins bind to the cellular stress response protein GADD34 and interfere with GADD34 functions. Mol. Cell. Biol. 23: 3477-3486

20. Yoo JH, Cheong MS, Park CY, Moon BC, Kim MC, Kang YH, Park HC, Choi MS, Lee JH, Jung WY, Yoon HW, Chung WS, Lim CO, Lee SY and Cho MJ (2004) Regulation of the dual specificity protein phosphatase, DsPTP1, through interactions with calmodulin. J. Biol. Chem. 279: 848-858

21. Kim MC, Panstruga R, Elliott C, Muller J, Devoto A, Yoon HW, Park HC, Cho MJ and Schulze-Lefert $P$ (2002) Calmodulin interacts with MLO protein to regulate defence against mildew in barley. Nature 416: 447-451

22. Kim MC, Lee SH, Kim JK, Chun HJ, Choi MS, Chung WS, Moon BC, Kang CH, Park CY, Yoo JH, Kang YH, Koo SC, Koo YD, Jung JC, Kim ST, Schulze-Lefert $\mathrm{P}$, Lee SY and Cho MJ (2002) Mlo, a modulator of plant defense and cell death, is a novel calmodulin-binding protein. Isolation and characterization of a rice Mlo homologue. J. Biol. Chem. 277: 19304-19314

23. Perruc E, Charpenteau M, Ramirez BC, Jauneau A, Galaud JP, Ranjeva R and Ranty B (2004) A novel calmodulin-binding protein functions as a negative regulator of osmotic stress tolerance in Arabidopsis thaliana seedlings. Plant $\mathrm{J}$. 38: $410-420$

24. Juqiang Y, Cixin $\mathrm{H}$ and Hong $\mathrm{Z}$ (2003) The BAG-family proteins in Arabidopsis thaliana. Plant Sci. 165: 1-7

25. Jurado LA, Chockalingam PS and Jarrett HW (1999) Apocalmodulin. Physiol. Rev. 79: 661-682

26. Rhoads $A R$ and Friedberg $F$ (1997) Sequence motifs for calmodulin recognition. FASEB J. 11: 331-340

27. Kawasaki H, Nakayama S and Kretsinger RH (1998) Classification and evolution of EF-hand proteins. BioMetals. 11: 277-295

28. Cheney RE and Mooseker MS (1992) Unconventional myosins. Curr. Opin. Cell Biol. 4: 27-35

29. Poetsch A, Molday LL and Molday RS (2001) The cGMP-gated channel and related glutamic acid-rich proteins interact with peripherin-2 at the rim region of rod photoreceptor disc membranes. J. Biol. Chem. 276: 48009-48016

30. Korschen HG, Beyermann M, Muller F, Heck M, Vantler M, Koch KW, Kellner R, Wolfrum U, Bode C, Hofmann KP and Kaupp UB (1999) Interaction of glutamic-acid-rich proteins with the CGMP signalling pathway in rod photoreceptors. Nature 400: 761-766

31. Liu J, Seul U and Thompson R (1997) Cloning and characterization of a pollenspecific cDNA encoding a glutamic-acid-rich protein (GARP) from potato Solanum berthaultii. Plant Mol. Biol. 33: 291-300

32. Gross A, McDonnell JM and Korsmeyer SJ (1999) BCL-2 family members and the mitochondria in apoptosis. Genes Dev. 13: 1899-1911
33. Martin SJ, Reutelingsperger CP, McGahon AJ, Rader JA, van Schie RC, LaFace DM and Green DR (1995) Early redistribution of plasma membrane phosphatidylserine is a general feature of apoptosis regardless of the initiating stimulus: inhibition by overexpression of Bcl-2 and Abl. J. Exp. Med. 182: 15451556

34. Ludovico P, Sousa MJ, Silva MT, Leao C and Corte-Real M (2001) Saccharomyces cerevisiae commits to a programmed cell death process in response to acetic acid. Microbiology 147: 2409-2415

35. Filonova LH, Bozhkov PV, Brukhin VB, Daniel G, Zhivotovsky B and von Arnold $S$ (2000) Two waves of programmed cell death occur during formation and development of somatic embryos in the gymnosperm, Norway spruce. J. Cell Sci. 113: 4399-4411

36. Fath $A$, Bethke $P$, Beligni $V$ and Jones $R$ (2002) Active oxygen and cell death in cereal aleurone cells. J. Exp. Bot. 53: 1273-1282

37. Jabs T (1999) Reactive oxygen intermediates as mediators of programmed cell death in plants and animals. Biochem. Pharmacol. 57: 231-245

38. Madeo F, Frohlich E, Ligr M, Grey M, Sigrist SJ, Wolf DH and Frohlich KU (1999) Oxygen stress: a regulator of apoptosis in yeast. J. Cell. Biol. 145: 757767

39. Schulz JB, Weller M and Klockgether T (1996) Potassium deprivation-induced apoptosis of cerebellar granule neurons: a sequential requirement for new mRNA and protein synthesis, ICE-like protease activity, and reactive oxygen species. J. Neurosci. 16: 4696-4706

40. Lamb C and Dixon RA (1997) The oxidative burst in plant disease resistance. Annu. Rev. Plant Physiol. Plant Mol. Biol. 48: 251-275

41. Banzet N, Richaud C, Deveaux Y, Kazmaier M, Gagnon J and Triantaphylides C (1998) Accumulation of small heat shock proteins, including mitochondrial HSP22, induced by oxidative stress and adaptive response in tomato cells. Plant J. 13: 519-527

42. Rao MV and Davis KR (1999) Ozone-induced cell death occurs via two distinct mechanisms in Arabidopsis: the role of salicylic acid. Plant J. 17: 603-614

43. Mittler $R$ (2002) Oxidative stress, antioxidants and stress tolerance. Trends Plant Sci. 7: 405-410

44. Greenberg JT and Ausubel FM (1993) Arabidopsis mutants compromised for the control of cellular damage during pathogenesis and aging. Plant J. 4: 327341

45. Bowling SA, Guo A, Cao H, Gordon AS, Klessig DF and Dong X (1994) A mutation in Arabidopsis that leads to constitutive expression of systemic acquired resistance. Plant Cell. 6: 1845-1857

46. Dietrich RA, Delaney TP, Uknes SJ, Ward ER, Ryals JA and Dangl JL (1994) Arabidopsis mutants simulating disease resistance response. Cell 77: 565-577

47. Rate DN and Greenberg JT (2001) The Arabidopsis aberrant growth and death2 mutant shows resistance to Pseudomonas syringae and reveals a role for NPR1 in suppressing hypersensitive cell death. Plant J. 27: 203-211

48. Holt III BF, Mackey D and Dangl JL (2000) Recognition of pathogens by plants. Curr Biol. 10: 5-7

49. Scorrano L and Korsmeyer SJ (2003) Mechanisms of cytochrome $c$ release by proapoptotic BCL-2 family members. Biochem. Biophys. Res. Commun. 304: 437-444

50. Demaurex N and Distelhorst $C$ (2003) Cell biology. Apoptosis - the calcium connection. Science 300: 65-67

51. Thomas SG and Franklin-Tong VE (2004) Self-incompatibility triggers programmed cell death in Papaver pollen. Nature 429: 305-309

52. Dangl JL, Dietrich RA and Thomas H (2000) Senescence and programmed cell death In Biochemistry and Molecular Biology of Plants, Buchanan B, Gruisem W and Jones R (eds) MD: American Society Plant Physiology pp. 1044-1100

53. Levine A, Pennell RI, Alvarez ME, Palmer R and Lamb C (1996) Calciummediated apoptosis in a plant hypersensitive disease resistance response. Curr Biol. 6: 427-437

54. Jongebloed U, Szederkenyi J, Hartig K, Schobert C and Komor E (2004) Sequence of morphological and physiological events during natural ageing and senescence of a castor bean leaf: sieve tube occlusion and carbohydrate backup precede chlorophyll degradation. Physiol Plant. 120: 338-346

55. Clough SJ, Fengler KA, Yu IC, Lippok B, Smith Jr RK and Bent AF (2000) The Arabidopsis dnd1 'defense, no death' gene encodes a mutated cyclic nucleotide-gated ion channel. Proc. Natl. Acad. Sci. USA 97: 9323-9328

56. Houdusse A and Cohen C (1995) Target sequence recognition by the calmodulin superfamily: implications from light chain binding to the regulatory domain of scallop myosin. Proc. Natl. Acad. Sci. USA 92: 10644-10647 
57. Munshi HG, Burks DJ, Joyal JL, White MF and Sacks DB (1996) $\mathrm{Ca}^{2+}$ regulates calmodulin binding to IQ motifs in IRS-1. Biochemistry 35: 15883-15889

58. Sondermann H, Ho AK, Listenberger LL, Siegers K, Moarefi I, Wente SR, Hartl FU and Young JC (2002) Prediction of novel Bag-1 homologs based on structure/function analysis identifies Snl1p as an Hsp70 co-chaperone in Saccharomyces cerevisiae. J. Biol. Chem. 277: 33220-33227

59. Sondermann H, Scheufler C, Schneider C, Hohfeld J, Hartl FU and Moarefi I (2001) Structure of a Bag/Hsc70 complex: convergent functional evolution of Hsp70 nucleotide exchange factors. Science 291: 1553-1557

60. Froesch BA, Takayama S and Reed JC (1998) BAG-1L protein enhances androgen receptor function. J. Biol. Chem. 273: 11660-11666

61. Schneikert J, Hübner S, Martin E and Cato AC (1999) A nuclear action of the eukaryotic cochaperone RAP46 in downregulation of glucocorticoid receptor activity. J. Cell Biol. 146: 929-940

62. Wang HG, Takayama S, Rapp UR and Reed JC (1996) Bcl-2 interacting protein, BAG-1, binds to and activates the kinase Raf-1. Proc. Natl. Acad. Sci. USA 93: 7063-7068

63. Bardelli A, Longati P, Albero D, Goruppi S, Schneider C, Ponzetto C and Comoglio PM (1996) HGF receptor associates with the anti-apoptotic protein BAG-1 and prevents cell death. EMBO J. 15: 6205-6212

64. Matsuzawa S, Takayama S, Froesch BA, Zapata JM and Reed JC (1998) p53inducible human homologue of Drosophila seven in absentia (Siah) inhibits cell growth: suppression by BAG-1. EMBO J. 17: 2736-2747

65. Kullmann M, Schneikert J, Moll J, Heck S, Zeiner M, Gehring U and Cato AC (1998) RAP46 is a negative regulator of glucocorticoid receptor action and hormone-induced apoptosis. J. Biol. Chem. 273: 14620-14625

66. Liu R, Takayama S, Zheng Y, Froesch B, Chen G, Zhang X, Reed JC and Zhang X (1998) Interaction of BAG-1 with retinoic acid receptor and its inhibition of retinoic acid-induced apoptosis in cancer cells. J. Biol. Chem. 273: 1698516992

67. Naishiro Y, Adachi M, Okuda H, Yawata A, Mitaka T, Takayama S, Reed JC, Hinoda Y and Imai K (1999) BAG-1 accelerates cell motility of human gastric cancer cells. Oncogene 18: 3244-3251

68. Zeiner M, Niyaz Y and Gehring U (1999) The hsp70-associating protein Hap46 binds to DNA and stimulates transcription. Proc. Natl. Acad. Sci. USA 96: 10194-10199

69. Tschopp J, Martinon F and Hofmann K (1999) Apoptosis: silencing the death receptors. Curr. Biol. 9: 381-384

70. Emanuelsson O, Nielsen H, Brunak S and von Heijne G (2000) Predicting subcellular localization of proteins based on their N-terminal amino acid sequence. J. Mol. Biol. 300: 1005-1016

71. Bannai H, Tamada Y, Maruyama O, Nakai K and Miyano S (2002) Extensive feature detection of N-terminal protein sorting signals. Bioinformatics 18: 298305

72. Suzuki M, Youle RJ and Tjandra N (2000) Structure of Bax: coregulation of dimer formation and intracellular localization. Cell 103: 645-654

73. Huh GH, Damsz B, Matsumoto TK, Reddy MP, Rus AM, Ibeas Jl, Narasimhan ML, Bressan RA and Hasegawa PM (2002) Salt causes ion disequilibriuminduced programmed cell death in yeast and plants. Plant J. 29: 649-659

74. Vacca RA, de Pinto MC, Valenti D, Passarella S, Marra E and De Gara L (2004) Production of reactive oxygen species, alteration of cytosolic ascorbate peroxidase, and impairment of mitochondrial metabolism are early events in heat shock-induced programmed cell death in tobacco Bright-Yellow 2 cells. Plant Physiol. 134: 1100-1112

75. Tiwari BS, Belenghi B and Levine A (2002) Oxidative stress increased respiration and generation of reactive oxygen species, resulting in ATP depletion, opening of mitochondrial permeability transition, and programmed cell death. Plant Physiol. 128: 1271-1281

76. Nibbe M, Hilpert B, Wasternack C, Miersch O and Apel K (2002) Cell death and salicylate- and jasmonate-dependent stress responses in Arabidopsis are controlled by single cet genes. Planta 216: 120-128

77. Xiao S, Brown S, Patrick E, Brearley C and Turner JG (2003) Enhanced transcription of the Arabidopsis disease resistance genes RPW8.1 and RPW8.2 via a salicylic acid-dependent amplification circuit is required for hypersensitive cell death. Plant Cell. 15: 33-45

78. Kawai-Yamada M, Jin L, Yoshinaga K, Hirata A and Uchimiya H (2001) Mammalian Bax-induced plant cell death can be down-regulated by overexpression of Arabidopsis Bax Inhibitor-1 (AtBI-1). Proc. Natl. Acad. Sci. USA 98: 12295-12300

79. Elbaz M, Avni A and Weil M (2002) Constitutive caspase-like machinery executes programmed cell death in plant cells. Cell Death Differ. 9: 726-733

80. Lacomme C and Santa Cruz S (1999) Bax-induced cell death in tobacco is similar to the hypersensitive response. Proc. Natl. Acad. Sci. USA 96: 79567961

81. Lee SH, Kim MC, Heo WD, Kim JC, Chung WS, Park CY, Park HC, Cheong YH, Kim CY, Lee KJ, Bahk JD, Lee SY and Cho MJ (1999) Competitive binding of calmodulin isoforms to calmodulin-binding proteins: implication for the function of calmodulin isoforms in plants. Biochim. Biophys. Acta 1433: $56-67$

82. Iwabuchi K, Li B, Bartel P and Fields S (1993) Use of the two-hybrid system to identify the domain of p53 involved in oligomerization. Oncogene 8: 1693-1696

83. James P, Halladay J and Craig EA (1996) Genomic libraries and a host strain designed for highly efficient two-hybrid selection in yeast. Genetics 144: 14251436

84. Iftner T, Elbel M, Schopp B, Hiller T, Loizou JI, Caldecott KW and Stubenrauch F (2002) Interference of papillomavirus E6 protein with single-strand break repair by interaction with XRCC1. EMBO J. 21: 4741-4748

85. Moon H, Baek D, Lee B, Prasad DT, Lee SY, Cho MJ, Lim CO, Choi MS, Bahk J, Kim MO, Hong JC and Yun DJ (2002) Soybean ascorbate peroxidase suppresses Bax-induced apoptosis in yeast by inhibiting oxygen radical generation. Biochem. Biophys. Res. Commun. 290: 457-462

86. Lagrimini LM, Burkhart W, Moyer M and Rothstein S (1987) Molecular cloning of complementary DNA encoding the lignin-forming peroxidase from tobacco: molecular analysis and tissue-specific expression. Proc. Natl. Acad. Sci. USA 84: $7542-7546$

87. Church GM and Gilbert W (1984) Genomic sequencing. Proc. Natl. Acad. Sci. USA 81: 1991-1995

88. Koch E and Slusarenko A (1990) Arabidopsis is susceptible to infection by a downy mildew fungus. Plant Cell 2: 437-445

89. Stone JM, Heard JE, Asai T and Ausubel FM (2000) Simulation of fungalmediated cell death by fumonisin B1 and selection of fumonisin B1-resistant (fbr) Arabidopsis mutants. Plant Cell 12: 1811-1822

\section{Supplementary Information accompanies the paper on Cell Death Differentiation website (http://www.nature.com/cdd).}

